\title{
„Otworzyło mi się wtedy okno na inny świat. Otworzyło mi to oczy na moje życie" 0 wydarzeniach (punktach zwrotnych) inicjujących próby zerwania przez recydywistów z przestępczym stylem życia
}

\begin{abstract}
Abstrakt
W artykule przedstawiono wyniki badań biograficznych przeprowadzonych wśród recydywistów odbywających karę pozbawienia wolności. Zainteresowaniem objęto doświadczenia mężczyzn (punkty zwrotne), które stanowiły wyraźny przełom w realizowanym stylu życia w więzieniu i sposobie myślenia o swoim życiu w ogóle. Punktem wyjścia dla analiz uczyniono następujące pytania: w jaki sposób rekonstruowane są przez recydywistów doświadczenia stanowiące punkty zwrotne, które drastycznie transformują ich wizję „siebie” i ich tożsamości widziane oczami innych? Jaką rolę odgrywają w tym procesie tzw. przypadkowe okoliczności życiowe, a jaki jest udział intencjonalnie organizowanych przez personel wydarzeń $\mathrm{w}$ obrębie resocjalizacji instytucjonalnej? Charakterystyce poddano cztery przełomowe doświadczenia, którym towarzyszyły silne emocje oraz które uruchomiły pracę biograficzną i działania nastawione na zerwanie z przestępczym stylem życia. Są to: reorientacja układu pozycji i ról społecznych w rodzinie, miłość do kobiety, nawrócenie religijne oraz udział w terapii uzależnień.
\end{abstract}

Słowa kluczowe: badania biograficzne, recydywiści, punkty zwrotne, kontakty więźniów z rodziną, nawrócenie religijne więźniów, terapia uzależnień w więzieniu.

\section{"A window onto a Different World Opened up for Me Then. My Eyes Opened and I Saw My Life": On the Turning Points in Breaking Away from the World of Crime}

\begin{abstract}
This article presents the findings from a biographical study of repeat offenders serving prison sentences. It focuses on the experiences of male participants, particularly
\end{abstract}

\footnotetext{
* Uniwersytet Łódzki, Wydział Nauk o Wychowaniu.
} 
the turning points in the ways in which the offenders evaluated their lives. The starting point for the analyses were the following questions: How do repeat offenders construct turning points which so dramatically transform their perceptions of themselves and their identity in the eyes of others? What role does blind chance play in the process of rehabilitation and what role is played by institutional interventions? Four types of turning points were identified and discussed in this study: a change of social roles in the family, love for a woman, religious conversion, and participation in addiction therapy. These turning points triggered strong emotions and led to biography work aimed at breaking away from habitual offending.

Keywords: biographical study, repeat offenders, turning points, offenders' family relationships, addiction therapy, religious conversion.

\section{Wprowadzenie}

Analizując kluczowe wydarzenia, które zmieniają dynamikę karier zawodowych, Everett Hughes (1984) dał początek dyskusji naukowej poświęconej zagadnieniu specyficznych doświadczeń mających charakter przełomu, swoistego zwrotu w przebiegu życia jednostki. Anzelm Strauss przyjął koncepcję „punktu zwrotnego” za podstawową kategorię w analizach przemiany tożsamości. Według niego są to momenty w życiu, które transformują własną wizję siebie jednostki oraz nadają jej określoną tożsamość widzianą oczami innych. Wartym podkreślenia jest to, że wydarzenia te powodują uświadomienie sobie przez jednostkę tego, że „nie jest już tą, jaką była" (Strauss 1977: 93). Zagadnienie to analizuje również Norman Denzin, określając te doświadczenia mianem epifanii - czyli olśnienia, objawienia - które są momentami interakcji odciskającymi piętno na ludzkim życiu (Denzin 1989).

Na gruncie rodzimego piśmiennictwa naukowego poświęconego resocjalizacji pojęcie to stanowi przedmiot rozważań Marka Konopczyńskiego (np. 2009). Zwraca on uwagę na specyficzny etap w procesie resocjalizacji, który daje początek przemianom tożsamościowym osoby przestępczej. Konopczyński nadaje zjawisku miano „olśnienia dewiacyjnego” i traktuje je jako rezultat szczególnego rodzaju postępowania za pomocą metod twórczej resocjalizacji. „Olśnienie dewiacyjne” to moment rozpoczynający żmudny i niezwykle trudny proces destygmatyzacji. Jak sam pisze: proces ten

rozpoczyna się od uświadomienia przez jednostkę niewłaściwego dotychczasowego życia (swojego nieszczęśliwego losu), które powoduje pełnienie dewiacyjnych ról społecznych (przestępcy, agresora, nieudacznika itp.), a więc od dostrzeżenia efektów procesu stygmatyzacji negatywnej. Uświadomienie to ma charakter „olśnienia” przypominającego nieco zjawisko „olśnienia schizofrenicznego”. Jest ono zaczątkiem nawrócenia, które rozpoczyna dramatyczny i długotrwały proces walki ze sobą samym (tamże: 71). 
W artykule przedstawiam wyniki badań biograficznych przeprowadzonych wśród recydywistów. Analizie poddałam specyficzne doświadczenia, które stanowiły przełom $\mathrm{w}$ ich dotychczasowym sposobie myślenia o sobie i życiu w trakcie odbywania kary pozbawienia wolności. Nie jest jednakże moim zamiarem analiza wydarzeń życiowych, które z perspektywy czasu można ocenić jako znaczące i przełomowe dla zmiany określonej aktywności życiowej (z przestępczej na nieprzestępczą). W artykule zainteresowaniem objęłam tylko te wydarzenia, które miały miejsce $\mathrm{w}$ trakcie pobytu $\mathrm{w}$ więzieniu, w swoim przebiegu były bardzo intensywne oraz którym towarzyszył szereg wyraźnych odczuć i reakcji charakterystycznych dla „punktów zwrotnych”: „zaskoczenie, szok, rozgoryczenie, niepokój, napięcie, zdumienie, pytania do siebie, a także potrzeba wypróbowania nowej jaźni, odkrycia i sprawdzenia nowych i często ekscytujących albo napawających strachem koncepcji” (Strauss 1977: 93). Samo „olśnienie dewiacyjne” nie jest bowiem gwarantem sukcesu resocjalizacyjnego. Jest jedynie pewnego rodzaju „wyzwalaczem” specyficznej pracy biograficznej.

\section{Punkty zwrotne (turning points) w badaniach karier przestępczych}

W badaniach tzw. karier przestępczych zagadnienie punktów zwrotnych (turning points) w próbach zerwania $\mathrm{z}$ dewiacyjnym stylem życia zajmuje ugruntowaną pozycję w piśmiennictwie obcojęzycznym, zwłaszcza amerykańskim i kanadyjskim. W Polsce odrębne doniesienia poświęcone analizom konkretnych wydarzeń (life events), które w perspektywie całożyciowej drogi przestępcy (deviant career) wpływają na zmianę aktywności z przestępczej na nieprzestępczą, wydają się być dość zaniedbanym terenem dociekań (por. Bernasiewicz, Noszczyk-Bernasiewicz 2016; Bernasiewicz 2015).

Analiza literatury kryminologicznej poświęconej przyczynom zaniechania działalności przestępczej każe sądzić, że największą uwagę badacze skupiają na relacjach interpersonalnych przestępcy z rodziną (np. Cid, Martí 2012; Sampson, Laub 2003), zatrudnieniu (Sampson, Laub 1993, 2003; Uggen 2000) oraz programach resocjalizacyjnych (Stevens 2012: 527-547; por. Niewiadomska 2007; Kieszkowska 2012). W tych trzech obszarach upatruje się decydujące czynniki przyczynowe zmiany. Podkreśla się również istotne znaczenie poczucia własnej skuteczności (Liem, Garcin 2014; por. Niewiadomska 2007) w procesie przemian. Wydarzenia inicjujące proces zmiany przestępcy lokuje się więc w czynnikach środowiskowych, instytucjonalnych i indywidualnych.

„Punkt zwrotny” jako podstawowa kategoria opisu zaniechania recydywy znajduje swoje szczególne miejsce na początku lat 90., zwłaszcza za sprawą pogłębionych badań Johna Lauba, Roberta J. Sampsona, Patricka Sharkeya (1993, 2003, 2010). Początkowo badacze wyłonili trzy punkty zwrotne w karierze dewiacyjnej, 
istotne z punktu widzenia zerwania z przestępczością: praca, małżeństwo ( $\mathrm{w}$ tym urodzenie się dziecka) oraz służba wojskowa. Jedną z perspektyw analizowania czynników sukcesu była także „wymiana” warunków środowiska życia (odcięcie się od dotychczasowego, przestępczego).

Co ciekawe, zmiana miejsca zamieszkania według niektórych badaczy powinna być traktowana jako zasadniczy „punkt zwrotny” w karierze dewiacyjnej wielokrotnych przestępców (Kirk 2012; Sharkey, Sampson 2010). Co więcej, zdaniem niektórych, dążenie do zmiany miejsca zamieszkania przestępców winno stanowić ważne zadanie dla służb społecznych. Postuluje się nawet zasadność obligowania byłych osadzonych do tego działania i podjęcia zatrudnienia $\mathrm{z}$ dala od swoich poprzednich środowisk życia, zwłaszcza podczas pierwszych, trudnych miesięcy po opuszczeniu zakładu karnego (Kirk 2013). Oprócz „fizycznego” zerwania z dewiacyjnym środowiskiem przestępczym służy ona bowiem pojawianiu się wydarzeń stanowiących punkty zwrotne (np. zawarcie małżeństwa, znalezienie pracy), które pełnią kluczową rolę w podtrzymywaniu zmiany stylu życia.

W tej perspektywie utrzymane są między innymi ciekawe doniesienia Davida S. Kirka (tamże), który punktem zwrotnym dla przerwania przestępczego stylu życia uczynił... huragan Katrina w Nowym Orleanie w 2005 r. Zniszczenia za sprawą żywiołu objęły szczególnie biedne dzielnice, często miejsca nacechowane silnym wskaźnikiem przestępczości. Były one także odbudowywane w drugiej kolejności i dlatego ich mieszkańcy zmuszeni byli zamieszkać w innych miejscach. Tak więc zniszczenia w sposób naturalny spowodowały konieczność opuszczenia tych dzielnic przez osoby zamieszkujące je od pokoleń i rozparcelowanie ich po różnych dzielnicach miasta, a nawet regionu. Kirk zadał sobie pytanie: czy czasowa zmiana zamieszkania powoduje okresowe „zawieszenie” działalności przestępczej, czy też może stać się katalizatorem zaniechania i prawdziwej zmiany stylu życia? Autor badań dowodzi spadku powrotu do przestępczości wśród dotychczas karanych i trwałego utrzymywania się niedewiacyjnego stylu życia recydywistów przymusowo wysiedlonych ze zniszczonych dzielnic. Wnioski swoje formułuje na podstawie kilkuletnich badań, mających na celu porównanie aktywności życiowej tych, którzy wrócili do swoich starych miejsc zamieszkania i tych, którzy wciąż żyją w odległych dzielnicach miasta.

Warto przy okazji nadmienić, że badacze analizujący wpływ zmiany miejsca zamieszkania na zerwanie $\mathrm{z}$ aktywnością przestępczą podkreślają jej autoteliczne wartości, tj. nie ma znaczenia rodzaj i jakość „nowej” dzielnicy, ile sam fakt „wyprowadzki" ze starej. Innymi słowy, nawet zamiana dotychczasowego środowiska życia na obiektywnie gorsze warunki socjoekonomiczne posiada duży potencjał sukcesu z punktu widzenia zerwania z przestępczym stylem życia (Laub, Sampson 2003).

Niektórzy badacze słusznie zwracają uwagę na to, że czynnikami różnicującymi sukces w zakresie zerwania z przestępczym stylem życia są wiek oraz długość 
odbywania kary pozbawienia wolności (Liem, Garcin 2014). Okazuje się, że o ile zatrudnienie, stabilna sytuacja zarobkowa stanowi ważny czynnik sukcesu w próbach zerwania z recydywą wśród starszych przestępców, to takiej zależności nie można już upatrywać w odniesieniu do młodych mężczyzn (por. Szczepanik 2015, 2016). Jeszcze na inną zależność wskazuje się w przypadku mężczyzn odbywających długoterminową karę pozbawienia wolności. Czynnikiem decydującym o sukcesie $\mathrm{w}$ próbach zerwania $\mathrm{z}$ dewiacyjnym stylem życia wydaje się tu być w największej mierze poczucie własnej skuteczności, w tym określony zestaw kompetencji i umiejętności, które są „produktem” oddziaływań penitencjarnych (por. Niewiadomska 2007), a nie zasoby społeczne (relacje z rodziną, zatrudnienie, instytucjonalna sieć wsparcia).

Badania każą sądzić, że więźniowie osadzeni na długie lata w jednostkach penitencjarnych doświadczają zupełnie innych „punktów zwrotnych” niż ci, którzy odbywają krótsze wyroki. Co więcej, te same czynniki, które stanowią źródło sukcesu dla przestępców z krótkimi wyrokami, mogą być przyczyną niepowodzeń w odniesieniu do tych, którzy opuścili więzienia po wielu latach. Zaobserwowano na przykład, że zawarcie małżeństwa (jako punkt zwrotny) w przypadku tych drugich stanowi o tyle czynnik ryzyka, że jest ono podejmowane pod wpływem specyficznej presji, jaką jest chęć szybkiego nadrobienia straconego czasu, „dogonienia" innych, uzupełnienia znaczącej luki w życiorysie. Badacze podkreślają, że grozi to poważnym ryzykiem porażki w konsekwencji nieprzemyślanej, spontanicznej decyzji. Determinacja ta powoduje bowiem swoistą łatwość angażowania się w relacje z kobietami „problemowymi” - uzależnionymi, uwikłanymi w środowisko przestępcze, z zaburzeniami zdrowia psychicznego itp. (Liem, Garcin 2014). Podobnie posiadanie dzieci przez mężczyzn pozostających długie lata w więzieniu lokuje się w grupie czynnika niepowodzeń, a nie sukcesu readaptacyjnego. Podkreśla się, że brak naturalnej, spontanicznej relacji, utrata bezpośredniego kontaktu $\mathrm{z}$ dzieckiem poprzez fakt pobytu w więzieniu ugruntowuje wykluczenie i stanowi jeden ze wskaźników szacowania niskiej pozycji społecznej (brak relacji z dzieckiem jako dowód na bycie złym ojcem w ogóle).

Natomiast szczególnym źródłem sukcesu jest posiadanie stabilnego zatrudnienia po opuszczeniu więzienia. Jednakże i tu pojawia się pewien problem. Badacze uważają, że tylko wtedy praca ta będzie posiadała cechy punktu zwrotnego, jeśli nie będzie jedynie tą, która zaspokaja potrzeby materialne byłego przestępcy, ile taką, w której może on w specyficzny sposób „zarządzać” swoim wizerunkiem eks-kryminalisty (np. doradca w terapii uzależnień, praca w instytucjach zajmujących się wsparciem społecznym osób wykluczonych itp.) (Liem, Garcin 2014). Takie doniesienia można ulokować w naukowej refleksji nad procesem destygmatyzacji i spełnianiem się w roli eks-dewianta (m.in. Konopczyński 2009). Zatrudnienie bywa także traktowane nie jako przyczyna zerwania z recydywą, ale jako rezultat zaniechania przestępczego stylu życia. Przykładowo, wielokrotni przestępcy nie 
nadają pracy znaczenia priorytetowego warunku dla udanych prób zerwania z przestępczością. Można zaryzykować stwierdzenie, że dla recydywistów praca pełni specyficzną rolę potwierdzania i ugruntowywania, a nie rozpoczynania swojej zmiany (Szczepanik 2016).

\section{Badania własne}

Ontologiczne przesłanki ujmowania świata społecznego recydywistów zaczerpnęłam z teorii symbolicznego interakcjonizmu (m.in. Blumer 2009; Hałas 2006). Rzeczywistość społeczna powrotnych przestępców ujawniała się w toku analizy interakcji, w których uczestniczyli mężczyźni, badania ich sposobów interpretowania i definiowania sytuacji (subiektywnych znaczeń) i wynikających z tego działań.

Przyjęcie perspektywy poznania wykraczającej poza indywidualne biografie jednostek i dającej warunki odkrywania ogólnych wzorów i mechanizmów kształtujących sens działania podmiotu oraz relacji społecznych, jakie są jego udziałem, umożliwiły mi procedury metodologii teorii ugruntowanej. Pojęcia i relacje opisane $\mathrm{w}$ niniejszym artykule zostały wygenerowane $\mathrm{z}$ danych, jakimi były pozyskane przeze mnie biografie mężczyzn $\mathrm{z}$ doświadczeniem co najmniej trzykrotnego pobytu w więzieniu. Podstawowy (acz niejedyny) materiał empiryczny stanowiły zapisy wywiadów narracyjnych i swobodnych (szerzej: Szczepanik 2015).

Poniżej zaprezentowane wyniki badań obejmują tylko te wydarzenia (punkty zwrotne), które stanowiły wyraźny moment - swoisty przełom w dotychczasowym stylu życia w więzieniu. Specyficzne doświadczenia uruchamiały poważne zmiany w sposobie myślenia o swoim życiu i sobie samym. Punktem wyjścia dla analiz uczyniłam następujące pytania: w jaki sposób rekonstruowane są przez recydywistów doświadczenia stanowiące punkty zwrotne, które rozpoczynają proces drastycznej transformacji ich wizji „siebie” i ich tożsamości widzianych oczami innych? Jaką rolę odgrywa w tym procesie przypadek, a jaki jest udział intencjonalnie organizowanych warunków w obrębie resocjalizacji instytucjonalnej, które sprzyjają zaistnieniu wydarzeń stanowiących punkty zwrotne?

Wyłonione przeze mnie wydarzenia, przyjmujące postać „punktów zwrotnych” w karierze przestępczej badanych recydywistów, spowodowały zmianę ich poglądów oraz zainicjowały działania sprzyjające zerwaniu z aktywnością dewiacyjną. Urzeczywistnieniem tych doświadczeń była modyfikacja dotychczasowego stylu życia więziennego (szerzej: Szczepanik 2015). Oznaczało to między innymi świadome podejmowanie działań przez recydywistów na rzecz osłabiania swojego wizerunku przestępcy poprzez np. unikanie przystępowania do koalicji międzyosobowych nastawionych na wzmacnianie wysokiej pozycji w grupie przestępczej, dążenie do udziału w projektach resocjalizacyjnych zorientowanych na zdobycie nowych kompetencji, koncentrowanie swojej uwagi na budowaniu planu aktywno- 
ści życiowej (wolnej od aktywności dewiacyjnej) po opuszczeniu zakładu karnego oraz budowanie (lub rekonstruowanie) więzi z rodziną i kręgiem znajomych spoza środowiska przestępczego.

\section{Drastyczna reorientacja układu sił i pozycji społecznej w relacjach z osobami znaczącymi. Nawiązanie nowej więzi}

Charakter, siła oraz jakość więzi skazanego z rodziną relatywnie często stanowią przedmiot badań i analiz naukowych. Badania te nadają rodzinie prokreacji status ważnych warunków społecznych sprzyjających readaptacji i zapobiegania recydywie, a nawet sprowadzają ją wprost do roli specyficznego narzędzia efektywnej resocjalizacji penitencjarnej (szerzej: Szczepanik, Miszewski 2016). Analiza „punktów zwrotnych" w trakcie odbywania kary pozbawienia wolności przez recydywistów pozwala sądzić, że zmiana charakteru relacji z członkami rodziny lub innymi osobami znaczącymi może być swoistym „wyzwalaczem” pracy biograficznej nastawionej na zmianę dotychczasowego stylu życia. Uwagę moją zwróciły specyficzne wydarzenia związane bezpośrednio z nawiązaniem więzi, odbudowaniem lub niespodziewanym zerwaniem relacji z kimś bliskim dla skazanego, znaczącym w jego życiu. W rekonstruowanych przez recydywistów przebiegach tych wydarzeń (rozciągniętych w określonym czasie) pojawiały się takie wrażenia i silne emocje, jak: szok, niedowierzanie, zaskoczenie, wzruszenie, gniew i euforia. Zaskoczeniem było dla recydywisty to, że bliska osoba (dorosłe dziecko, partnerka życiowa) niespodziewanie zrywa relację ze skazanym lub przeciwnie - po wielu latach nieobecności ktoś odnawia kontakt z mężczyzną albo też pojawia się nowa kobieta, która przejawia silną wiarę w mężczyznę oraz obdarza go głębokim uczuciem.

W krótkiej perspektywie czasu (po danym wydarzeniu) doświadczenia te uruchamiały u skazanego inne niż dotychczas myślenie o sobie i swoim życiu. Wydarzeniem przełomowym w życiu przestępcy jest więc wyraźna zmiana pozycji w środowisku rodzinnym lub w relacji z osobą znaczącą. Mężczyzna traci stabilną i silną pozycję w układzie rodzinnym:

15 listopada tego roku rozpadł mi się związek. Napisała, że nie chce już dłużej czekać. Wyjechała na stałe do Anglii i że już jej nie znajdę, bo ona już nie wyobraża sobie życia ze mną. [R2]

lub przeciwnie - zyskuje nową i taką, jakiej nigdy nie miał.

Ja sam jestem w szoku, że tak w ogóle to wyszło. Znam ją dziecka. Bo ona mieszkała w ... obok mojej klatki, w tym samym bloku. I to była ... jest cały czas jest od dziecka przyjaciółką mojej siostry (...). No i przez ten czas co ja siedzę w więzieniu ... w ogóle to się z nią ... ona jest zakochana we mnie, nie wiem od dziecka chyba to 
nawet mówiła. No i odkąd ja siedzę w więzieniu ona do mnie też do mnie na widzenia przyjeżdża tylko ... jako koleżanka przyjeżdżała. Teraz się to zmieniło (...). Dla mnie to niewiarygodne. [R18]

Ja nie miałem dobrego kontaktu z tatą nigdy. Nienawidziłem go. Za to, że odszedł od nas jak byłem mały. Do tego 20 roku to był dla mnie bo był. (...) Non stop mamy kontakt telefoniczny, non stop mi mówi, gdzie mnie zabierze, jak wyjdę stąd ... że mam do niego do Anglii jechać i ... jakby odkryłem to, że mam kogoś kto ... komu na mnie zależy, tak? I chcę już tam wyjechać, żeby do ... żeby z nim zamieszkać, jak prawdziwy ojciec z synem. I żeby to moje życie zaczęło inaczej się toczyć ... żebym już nie musiał wracać do kryminału. Bo jak się ma prawdziwą rodzinę, to jest inaczej, tak? [R11]

Zwrot w sposobie myślenia o sobie i swoim życiu nie jest rezultatem podjęcia decyzji, ale efektem pewnego procesu. Na jego strukturę składają się cztery elementy, a właściwie następujące po sobie etapy (szok i niedowierzanie, silne emocje, kryzys i podjęcie pracy biograficznej). Przykładem rekonstrukcji tych etapów jest fragment narracji mężczyzny mającego doświadczenie wielu pobytów i lat spędzonych w więzieniu. Mężczyzna był najstarszym bratem w wielodzietnej rodzinie. W krótkich „przerwach” pomiędzy kolejnymi skazaniami cieszył się autorytetem wśród członków rodziny i zarządzał gospodarstwem domowym. Analiza biografii każe sądzić, że rodzeństwo i matka czuli przed nim respekt powodowany przede wszystkim lękiem (był wybuchowy, agresywny, autorytarny) oraz tym, że posiadał bardzo wysoką pozycję w lokalnym środowisku przestępczym (małego miasta). Podczas odwiedzin w zakładzie karnym młodszy brat nagle zakwestionował autorytet skazanego. Wyznanie brata stanowiło dla badanego zaskoczenie:

I mi mówi, coś takiego mówi: „ja swoje odcierpiałem. I już nie chcę dalej tak jak teraz czy tak jak ty masz”. Ja się oburzyłem i mówię: „ale co?”. A on mi mówi, że chciał być jak ja, ale czasem, że miał do mnie wstyd. (...) I wie pani co, ja wtedy ... mi ... to tak ... że ktoś mi powiedział „ja nie chcę być jak ty!”. [R14]

Niespodziewane wydarzenie wywoływało bardzo silne emocje u recydywisty:

(...) jak wtedy on mi to mówił, to mnie potem było żal. Zły byłem. (...) I jak o tym myślę ... to jakby spadł młot na łeb (...) nie mogłem spać, biłem się z myślami. [R14]

Negatywne emocje dały początek kryzysowi emocjonalnemu, który następnie uruchamiał określone refleksje i sprzyjał podejmowanej pracy biograficznej:

Bo to mój brat jest, a ja jaki brat jestem? Że starszy, to powinien brać ze mnie przykład, to ja powinienem był o niego ... opiekować się nim. A ja albo siedziałem we więzieniach, albo miałem własne sprawy. A on w domu dziecka. (...) I mówię 
sobie, mam prawie 30 lat do w sumie odsiedzianego wyroku. (...) I mówię: nie! ... Nie znam swoich dzieci. Nie mam kontaktu z jednym synem, później urodził mi się drugi. (...) Praktycznie cały czas we więzieniach, albo się ukrywałem. To co ja w tym domu ... raz byłem, raz nie, a jeszcze jak byłem, to demolka. [R14]

Szczególne miejsce w procesie zmiany myślenia o swoim życiu i próbach zrywania $\mathrm{z}$ wizerunkiem recydywisty ma zawiązanie silnych relacji z nowo poznaną kobietą. Wielokrotnie powracający do przestępczości mężczyźni mają wysoką świadomość czynników, które powodowały porażki w podejmowanych próbach unikania powrotu do więzienia. Celowo rozróżniam działania recydywistów na rzecz minimalizowania ryzyka (ponownego) skazania na karę pozbawienia wolności oraz te, które nastawione są na zerwanie z przestępczym stylem życia. Ci, którzy mają za sobą wiele lat więzienia, ale ich doświadczeniem nie stało się wydarzenie pozwalające na doznanie „olśnienia dewiacyjnego” będą budować plan swojej aktywności życiowej na wolności nastawionej przede wszystkim na kamuflowanie swojego wizerunku (szerzej: Szczepanik 2016) tak, by nie wrócić do zakładu karnego kolejny raz. W plany ich wpisuje się między innymi poszukiwanie „kobiety kolejnej szansy”, zwykle takiej, która ustabilizuje życie recydywisty po opuszczeniu więzienia, a także będzie stanowić swoiste alibi dla przedstawicieli formalnej kontroli społecznej. W tym przypadku związek z kobietą jest silnym atutem, a nawet podstawowym warunkiem powodzenia redefiniowania swojego statusu społecznego w relacjach z otoczeniem. Badany nadaje mu także znaczenie lekarstwa - warunku ułatwiającego walkę z pokusami i zniewoleniami, a kobiecie przypisuje miano „strażniczki” jego pokus. Kobieta sprzyja powstrzymywaniu się recydywisty przed popełnianiem przestępstw lub nieangażowaniu się w szczególnie ryzykowne przedsięwzięcia „wspólników”.

Już nawet myślałem, że nie wrócę do kryminału nigdy. (...) układałem sobie życie można powiedzieć jak normalny człowiek z kobietą. I to mnie uratowało [długoletnia przerwa w odbywaniu kary pozbawienia wolności]. [R31]

Zawiązanie silnych relacji z nowo poznaną kobietą może jednak stanowić wydarzenie, które będzie punktem zwrotnym dla dotąd realizowanego i wyznawanego stylu życia przestępczego. W tym przypadku związek z kobietą tworzy bowiem bardzo często silne zaplecze wolnościowe recydywisty oraz staje się bezpośrednim motorem napędowym dla prób działań na rzecz zerwania z wizerunkiem przestępcy. Analiza biografii recydywistów pozwala sądzić, że miłość do kobiety, albo specyficzny rodzaj „zarażenia się” głęboką wiarą partnerki w nowe życie, jej optymizmem stanowiło okres, w trakcie którego mężczyźni przeformułowywali swoje plany - z unikania więzienia (poprzez powstrzymywanie się przed przestępczością) na tworzenie warunków na rzecz rzeczywistego zerwania z dewiacyjną aktywnością (przemiany tożsamościowe). 
Będąc w więzieniu poznałem moją późniejszą żonę. Zmieniła mój wyrok do góry nogami. Będąc jeszcze w więzieniu miałem w głowie tylko to jak sobie ułożymy wspólnie życie jak opuszczę jednostkę. Moja przestępcza przeszłość nie była problemem dla mojej przyszłej żony. Podczas wyroku często pisaliśmy do siebie listy i mieliśmy wspólne plany. Przyjeżdżała na spotkania do zakładu i coraz bardziej byliśmy sobie coraz to bliscy. Otworzyło mi się wtedy okno na inny świat (...) Otworzyło mi to oczy na moje życie. [R1]

Bywa, że pod wpływem silnego kryzysu emocjonalnego i uruchomienia pracy biograficznej powodowanej reorientacją układu pozycji społecznej w środowisku rodzinnym mężczyźni decydują się na udział w terapii podczas pobytu w zakładzie karnym.

\section{Udział w terapii uzależnień}

W zakładach karnych skazany może odbywać część kary w warunkach systemu terapeutycznego. Oddziaływania wobec skazanych uzależnionych od alkoholu prowadzone są $\mathrm{w}$ formie trzymiesięcznych stacjonarnych programów terapeutycznych, natomiast dla osób borykających się z problemem narkomanii przewiduje się sześciomiesięczną terapię. Wykorzystuje się $w$ nich takie same metody, jak w pozawięziennych placówkach lecznictwa odwykowego (np. pracę metodą społeczności terapeutycznej). Najczęstszą przyczyną zgłoszenia się więźnia na terapię jest presja personelu więziennego lub decyzja sądu. Bywa, że sam osadzony podejmuje starania w tym zakresie.

Rekonstrukcji kryzysu emocjonalnego doświadczanego w przeszłości w rezultacie udziału w terapii uzależnień i będącego elementem punktu zwrotnego (rozumianego jako proces) towarzyszyły wyraźne stany poruszenia, co ilustruje poniższy fragment narracji:

(...) Jakby znał moje dzieciństwo i zacząłem się zastanawiać, co jest grane? (...) utwierdziłem siebie, że moim problemem było ... właśnie dorastanie, to jaki byłem jak byłem mały ... To, że w domu mi mówili, że się z domu nie wynosi, że się nie donosi ... ja to ... wtedy już ... myślałem, że to źle, było niby to dobre i zastanawiałem się, zacząłem się zastanawiać sam do siebie, że ... pogubiłem się. Tak samo i tu. Tu mówili, że się nie sprzedaje ... z drugiej strony, no jak można nie sprzedawać, mówię, skoro coś jest złe?. To był taki czas powiem pani szczerze, że w ogóle mi się pomieszało ... nie wiem jak to powiedzieć. Co ja robię?! [dłuższa pauza] Robiłem ... jaki ... to znaczy jak to wszystko [dłuższa pauza]. To byłem powiem pani ... wtedy taki zły. [Mówi szybko do *] Nie wiem na co, nie wiem, nie na siebie, no na siebie* ... no bo przestało mi się wszystko jakoś układać. Nie wiem ... zgadzać, nie? Tak jakby do tej pory wiedziałem i się zgadzało, a teraz coś się nie zgadza. To mnie wtedy nosiło, byłem ... no bardzo zły byłem. Bardzo jakiś ... nie wiem (...) Czasem 
sobie odpowiadam: kim ja ku-wa jestem? Okazało się, że zwykłym bandytą. Wcześniej to ja myślałem ... miałem w sobie taki tok myślenia, że jestem wysoko. Jestem wysoko w więzieniu, moje zdanie się w więzieniu liczy ... Na wolności też jestem wysoko ... tylko zaczęłem się zastanawiać ... po której stronie wysoko? Nie jestem ani ojcem, ani dobrym mężem, nie byłem dobrym synem ... nawet nie byłem dobrym bratem. [R14]

Terapeuci „rozliczają” z przeszłości (bilans zysków i strat), a także dążą do tego, by przestępca opracował plany na przyszłość w oparciu o posiadane zasoby. Nie oznacza to naturalnie automatycznej zmiany nastawienia, ale może być inspiracją dla podjęcia autentycznej pracy biograficznej. W badaniach własnych wyłoniłam osoby, dla których to właśnie udział w terapii uzależnień był przełomem w sposobie definiowania swojego życia, mimo że znaleźli się na niej wbrew swojej woli i nie brali pod uwagę ani nie odczuwali wcześniej jakiejkolwiek potrzeby zmiany swojego życia.

Jeden mój kumpel mówi, że był na takiej terapii. Mówi: „posłuchaj, jedź tam” mówi - „nic się nie wtrącaj” - mówi - „bo cię zjadą!”. Mówię: „jak to?”. A on - „są społeczności” - mówi - „będą na ciebie naciskać”. [R14]

Po raz pierwszy dotarło jakby do mnie, że są ludzie, których zawiodłem. (...) jaki los zgotowałem moim dzieciom. (...) Byłem wściekły na społeczności. Krzyczałem na wszystkich bo ... jakbym chciał to zagłuszyć w sobie, tak? [R21]

Musiałem to wszystko spisać i...a potem na mnie naciskali na tej terapii. Wszyscy yy i psycholog i inni osadzeni...Ja pomyślałem sobie wtedy, że nic mnie w życiu już nie złamie, a wtedy mnie złamano. Wie pani, że się popłakałem przy wychowawcach? [R11]

Doświadczenie terapeutyczne powoduje, że recydywista zyskuje umiejętności analizowania swojego życia, a terapia dostarcza mu specyficznych narzędzi do pracy nad sobą. Jeśli terapia była punktem zwrotnym dla recydywistów, to między innymi dlatego, że wzbudziła w nich głęboką refleksję nad splotem okoliczności i warunków, które wcisnęły go na dewiacyjną ścieżkę życia.

\section{Nawrócenie religijne}

Nawrócenie i wychowanie religijne (czyli wykorzystanie określonych wartości i rytuałów w procesie resocjalizacji więziennej) było niejednokrotnie przedmiotem analiz naukowych (np.: Jahnson 1997; Kerley 2005; Kerley, Copes 2009). Znaczenie udziału więźniów w praktykach religijnych czy studiowanie przez nich biblii opisywane bywa w piśmiennictwie naukowym w kontekście przemiany duchowej 
i pracy z emocjami (np. radzenie sobie z poczuciem winy, osamotnieniem, przeświadczeniem o stracie swojego życia), więzi osobowych (np. pożądanych relacji między więźniami) czy „znalezienia nowego sposobu na życie” (Clear i in. 2000: 60). Na warunki skuteczności podobnych projektów przeobrażeń swojego dotychczasowego życia wskazuje m.in. J. Lofland i in. (2006: 220) i pisze o tym następująco: „stare modele działania wyczerpały się, zawiodły lub zostały zakłócone albo mogły się wkrótce wyczerpać, zawieść lub ulec zakłóceniu, i zetknęły się z możliwością (lub potrzebą) łatwego spróbowania czegoś nowego w życiu".

Czym może być więc nawrócenie religijne więźniów? Jakie ma dla nich znaczenie w działaniach na rzecz budowania określonego wizerunku? Analiza materiału empirycznego pozwoliła mi wyłonić różne oblicza nawrócenia religijnego. Nawrócenie religijne może być instrumentem nadawania swojemu życiu warunków niezależnych od siebie, a także może ono być narzędziem kompensowania deprywacji emocjonalnych i minimalizowania poczucia osamotnienia:

Powiedzieli: czytaj, to wszystko ci otworzy oczy i rozjaśni ci w głowie. Wiem, że u nich mam wsparcie. Wiem, że mam wsparcie (...). Są bardzo, bardzo fajni ludzie. Przyjąłem Jezusa do swojego serca. Czytam dużo pismo święte. I to mi pomaga. To mi pomaga. Widocznie, skoro tak ma być no to ... tak zadecydował Bóg. Ja teraz nie walczę z sobą, nie siłuję się. Co ma być to będzie. [R16]

Nawrócenie religijne przyjmuje również postać specyficznego nastawienia w trakcie odbywania kary pozbawienia wolności (określić to można mianem nawrócenia „tu i teraz”). Służy ono wytwarzaniu wizerunku osoby „już zresocjalizowanej”, czyli „zasługującej na wolność”. Więźniowie deklarują akty skruchy i operują technikami neutralizowania swojej winy, odwołując się do wartości chrześcijańskich (w myśl logiki: do tej pory postępowałem źle, ponieważ nie znałem i nie rozumiałem przykazań boskich).

W końcu - może ono stanowić punkt zwrotny (rozumiany jako proces inicjujący realne próby zerwania $\mathrm{z}$ przestępczym stylem życia). Pomijając kwestie związane z rzeczywistą przemianą duchową, dodatkowym czynnikiem wzmacniającym tę przemianę jest bliskość z innymi członkami wspólnoty stanowiącej określoną grupę religijna, zwłaszcza „nawracających”.

\section{Punkt zwrotny i co dalej?}

Zrekonstruowane powyżej punkty zwrotne w biografiach recydywistów spowodowały zmianę określonego stylu odbywania kary pozbawienia wolności. Jako że niektóre z wydarzeń były przez badanych rekonstruowane z czasów „poprzednich wyroków”, nie można uznać, że wydarzenia te stanowią skuteczny przełom dla zerwania z przestępczym stylem życia (trafili przecież do więzienia co najmniej na 
kolejny raz). Oznacza więc to, że punkt zwrotny nie jest wystarczającym czynnikiem rzeczywistej przemiany, której wskaźnikiem jest zerwanie z przestępczym stylem życia. Lokując zjawisko w koncepcji destygmatyzacji, należy podkreślić, że jest to wydarzenie niezbędne dla uruchomienia pracy biograficznej, acz stanowiące (jedynie) punkt wyjścia dla dalszych działań, które - jak to ujął Bronisław Urban (2004) - są rodzajem wręcz nadludzkiego wysiłku podejmowanego przez przestępcę.

Drogę destygmatyzacji musi odbyć sam, co nie oznacza, że powinien być pozbawiony wsparcia. Owo „wsparcie” tkwi w zasobach środowiskowych (związanych bezpośrednio z punktem zwrotnym), indywidualnych (np. poczucie skuteczności, posiadane kompetencje), jak również instytucjonalnych (rola personelu resocjalizacyjnego $\mathrm{w}$ podtrzymywaniu procesu przeobrażeń zainicjowanego przez punkt zwrotny). Bez względu jednak na to, czy wydarzenia te owocują skutecznym zerwaniem z przestępczym stylem życia, czy też kończą się porażką w podejmowaniu takich prób są niezwykle ważne w biografiach recydywistów. Nawet ci recydywiści, którzy „nie skorzystali” z punktu zwrotnego, jaki stał się ich doświadczeniem w czasie poprzednich pobytów w więzieniu, rekonstruują te wydarzenia jako niezwykle istotne i ważne w ich życiu. Nawet w sytuacji porażki w próbach zerwania z przestępczością recydywista już nigdy nie jest tym, kim był przed „olśnieniem".

W tym miejscu warto również wskazać na czynnik sprzyjający podejmowaniu pracy biograficznej przez recydywistów, jakim jest nabyty „język resocjalizacji”. Co ciekawe, jest on także pomocny w przypadku radzenia sobie $\mathrm{z}$ dyskomfortem i frustracją powodowaną porażką prób zerwania z przestępczością pod wpływem wydarzeń stanowiących punkt zwrotny.

Czym jest „nabyty język resocjalizacyjny”? Otóż jest to swego rodzaju produkt instytucjonalnej resocjalizacji, a właściwie bogatych doświadczeń związanych z licznymi pobytami w różnorodnych placówkach wsparcia społecznego, terapii i reedukacji. Język ten jest przyswajany przez recydywistów w toku codziennych interakcji z personelem (np. „Jakie oni mają na to słowo? Zaraz...jak to było...o, roszczeniowość!") oraz udziału w zajęciach resocjalizacyjnych, psychoedukacyjnych, terapii uzależnień itp.

Nabyty „resocjalizacyjny” język instytucji to nowy język opisu wydarzeń i sytuacji, dający recydywistom możliwość nadawania interpretacjom swojego życia statusu zobiektywizowanych znaczeń. Jest to także swoisty „kod” służący do porozumiewania się z tzw. ,normalnym społeczeństwem” (szerzej: Chomczyński 2014; Szczepanik 2015). Jest to oficjalna nomenklatura systemu, wywodząca się bezpośrednio $\mathrm{z}$ piśmiennictwa naukowego (będąca $\mathrm{w}$ istocie produktem teorii), przenoszona na pole oddziaływań leczniczo-terapeutycznych, metodycznych, prawno-formalnych itp. Nabycie owego języka pełni funkcję dodatnią - umożliwia recydywiście bycie świadomym „użytkownikiem” swojej osobowości, rozumienia splotu okoliczności i mechanizmów, które go ukształtowały i wpływały na jego 
życie („Pobiłem ją wtedy, a tak naprawdę to była moja projekcja, wyżyłem się za to moje niepowodzenie w pracy”.). Odgrywa również negatywne znaczenie - służyć może bowiem do operowania rozbudowanymi definicjami technik neutralizacji swojej dewiacji czy instrumentalnego zarządzania negatywną stygmatyzacją („Nie mam co nawet szukać pracy z takimi tatuażami” - nie mam wyjścia, muszę kraść). Może również stanowić wyrafinowany sposób wytwarzania wizerunku osoby, która „się zresocjalizowała” poprzez eksponowanie sukcesu pedagogicznego i prezentowanie siebie zgodnie z oczekiwaniami otoczenia („Wiem, że moje zachowanie nie jest poprawne”; „Nie jestem już roszczeniowy”; „Z dzieciństwa to tak raczej nie mam złych wspomnień, to znaczy te przestępstwa, które popełniałem, to są złe, tak?").

W odniesieniu do punktów zwrotnych język instytucji jawi się jako zasób i jako przeszkoda w pracy nad biografią (recydywistów). Pomaga w budowaniu objaśnień „tego co się przytrafiło” (punktu zwrotnego), pomaga też porządkować wizję przyszłego ja i racjonalizować cierpienie będące konsekwencją „olśnienia dewiacyjnego”. W przypadku braku warunków dla podtrzymywania „zmiany” język ten nabiera innego znaczenia: pomaga zagłuszać te „olśnienia” i radzić sobie z frustracją poprzez stosowanie różnych samousprawiedliwień czy lokowanie swoich porażek w systemie i czynnikach niezależnych od siebie.

Analiza piśmiennictwa naukowego oraz badania własne wskazują, że punkty zwrotne w biografiach przestępców są zarówno dziełem przypadku, jak i intencjonalnych zabiegów instytucjonalnych. „Wyzwalaczami” punktów zwrotnych jest w pierwszej kolejności rodzina lub osoby znaczące (np. ukochana kobieta). Rekonstrukcja lub stworzenie rodziny, bliskich więzi i relacji stanowi poważny przełom i może stać się przyczyną zaniechania przestępczości. Oczywiście możliwości takie stwarzają poznane kobiety lub ci znaczący członkowie rodziny, którzy nie są związani ze środowiskiem przestępczym i stoją niejako „na straży” zachowań recydywisty (np. Samson, Laub 1993; Szczepanik 2016).

W badaniach własnych wyłoniłam pewien rodzaj punktu zawrotnego, którego nie udało mi się znaleźć dotąd w piśmiennictwie poświęconym zjawisku. Podkreśla się bowiem pozytywne relacje, jakie udaje się zawiązać przestępcom, i ich rolę $\mathrm{w}$ próbach zrywania $\mathrm{z}$ dotychczasowym stylem życia. Analiza narracji badanych przeze mnie recydywistów pozwoliła mi wyodrębnić przeciwny rodzaj relacji, a mianowicie utratę dotąd posiadanego autorytetu, zerwanie więzi. Wydarzenie to wywołało u recydywistów poważny kryzys psychiczny i uruchomiło pracę biograficzną nastawioną na zmianę.

Drugi rodzaj „wyzwalaczy” punktów zwrotnych tkwi w warunkach tworzonych intencjonalnie przez instytucję penitencjarną. W biografiach mężczyzn był to udział $\mathrm{w}$ terapii uzależnień od narkotyków. W trakcie trwającej pół roku terapii 
recydywista „odkrywa” swoje życie na nowo i przyjmuje inną perspektywę jego oceny. Jest to dramatyczne w swoim przebiegu doświadczenie, które przestępcy próbują zagłuszać, eliminować czy zaprzeczać ich istocie. W przypadku odpowiednich wzmocnień ze strony personelu oraz podjęcia działań nastawionych na odbudowę zerwanych lub zaburzonych relacji z osobami znaczącymi (spoza środowiska przestępczego) udział $\mathrm{w}$ terapii odbija bardzo wyraźne piętno w biografii recydywisty. Zasobem instytucjonalnym jest tu również nabyty przez recydywistę „fachowy" język opisu swojej sytuacji życiowej - zwłaszcza pod wpływem udziału w takiej terapii (ale nie tylko).

Na zakończenie warto zasygnalizować obustronny charakter oddziaływania na siebie zasobów społecznych przestępców (np. relacja z kobietą) i instytucjonalnych (np. udział w terapii). Przykładowo, zależność ta jest następująca - pod wpływem poznania kobiety (punkt zwrotny) więzień podejmuje decyzję o udziale w programie resocjalizacyjnym, w ramach którego rozwinie określone zasoby osobowościowe czy kompetencje społeczne. Również możemy mieć do czynienia z sytuacją odwrotną: udział w terapii pod wpływem presji formalnej powoduje niezamierzoną z punktu widzenia przestępcy zmianę (punkt zwrotny) w sposobie myślenia, kolejno podtrzymywaną przez poznanie kobiety czy zatrudnienie (Szczepanik 2016).

\section{Bibliografia}

Becker H. (2009) Outsiderzy: studia z socjologii dewiacji, Warszawa, Wydawnictwo Naukowe PWN.

Bernasiewicz M. (2013) Doświadczenia religijne i konwersja jako potencjał w resocjalizacji w: Tożsamość kulturowo-cywilizacyjna dewiantów a ich reintegracja społeczna, M. Konopczyński, A. Kieszkowska (red.), Kraków, Oficyna Wydawnicza „Impuls”.

Bernasiewicz M. (2015) Pojęcie resocjalizacji (treatment, social rehabilitation) w perspektywie międzynarodowej i interdyscyplinarne, „Nauki o Wychowaniu. Studia Interdyscyplinarne", nr 1, s. 155-156.

Bernasiewicz M., Noszczyk-Bernasiewicz M. (2015) Punkty zwrotne (turning points) w przestępczej karierze. Szansa dla resocjalizacji/rewitalizacji nieletnich przestępców, „Chowanna”, nr 44, s. 103-116.

Blumer H. (2009) Interakcjonizm symboliczny. Perspektywa i metoda, Kraków, Zakład Wydawniczy Nomos.

Chomczyński P. (2014) Działania wychowanków schronisk dla nieletnich i zakładów poprawczych: socjologiczna analiza interakcji grupowych, Łódź, Wydawnictwo Uniwersytetu Łódzkiego. 
Cid J., Martí J. (2012) Turning points and returning points: Understanding the role of family ties in the process of desistance, „European Journal of Criminology”, no 6, s. 603-620.

Clear T. R., Hardyman P. L., Stout B., Lucken K., Dammer H. R. (2000) The value of religion in prison an inmate perspective, „Journal of Contemporary Criminal Justice”, no 1 , s. 53-74.

Giordano P., Cernkovic S. A., Rudolph J. L. (2002) Gender, Crime, and Desistance: Toward a Theory of Cognitive Transformation, „American Journal of Sociology”, no 4, s. 990-1064.

Denzin N. (1989) Interpretive Interacionism, Newbury Park CA, Sage.

Hałas E. (2006) Interakcjonizm symboliczny. Społeczny kontekst znaczeń, Warszawa, Wydawnictwo Naukowe PWN.

Hughes E. (1984) The sociological eye: Selected papers, Transaction publishers, New Brunswick.

Johnson B. R., Larson D. B., Pitts T. C. (1997) Religious programs, institutional adjustment, and recidivism among former inmates in prison fellowship programs, "Justice Quarterly", no 1, s. 145-166.

Kerley K. R., Copes H. (2009) „Keepin' My Mind Right”. Identity Maintenance and Religious Social Support in the Prison Context, „International Journal of Offender Therapy and Comparative Criminology", no 2, s. 228-244.

Kerley K. R., Todd L. M., Blanchard T. C. (2005) Religiosity, religious participation, and negative prison behaviors, "Journal for the Scientific Study of Religion”, no 4, s. 443-457.

Kieszkowska A. (2012) Inkluzyjno-katalaktyczny model reintegracji społecznej skazanych. Konteksty resocjalizacyjne, Kraków, Oficyna Wydawnicza „Impuls”.

Kirk D. S. (2009) A natural experiment on residential change and recidivism: Lessons from Hurricane Katrina, „American Sociological Review”, no 3, s. 484-505.

Kirk D. S. (2012) Residential change as a turning point in the life course of crime: desistance or temporary cessation? „Criminology”, no 2, s. 329-358.

Konopczyński M. (2009) Współczesne kierunki zmian w teorii i praktyce resocjalizacyjnej. Twórcza resocjalizacja - od korekcji do rozwoju, „Probacja”, nr 1, s. 63-87. 
Laub J. H., Sampson R. J. (1993) Crime in the Making. Pathways and Turning Points through Life, Cambridge, Harvard University Press.

Laub J. H., Sampson R. J. (2003) Shared Beginnings, Divergent Lives: Delinquent Boys to Age 70., Cambridge, Harvard University Press.

Liem M., Garcin J. (2014) Post-Release Success among Paroled Lifers, „Laws”, no 3, s. 798-823.

Lofland J., Snow D. A., Anderson L., Lofland L. H. (2006) Analiza układów społecznych. Przewodnik metodologiczny po badaniach jakościowych, Warszawa, Wydawnictwo Naukowe PWN.

Niewiadomska I. (2007) Osobowościowe uwarunkowania skuteczności kary pozbawienia wolności, Lublin, Wydawnictwo KUL.

Sampson R., Laub J. (1993) Crime in the Making. Pathways and Turning Points through Life, Cambridge, Harvard University Press.

Sampson R. J., Laub J. H. (2003) Life-course desisters? Trajectories of Crime among Delinquent Boys Followed to Age 70., „Criminology”, no 3, s. 301-340.

Sharkey P., Sampson R. J. (2010) Destination effects: Residential mobility and trajectories of adolescent violence in a stratified metropolis, „Criminology”, no 3, s. 639-682.

Stevens A. (2012) 'I am the person now I was always meant to be': Identity reconstruction and narrative reframing in therapeutic community prisons, "Criminology and Criminal Justice", no 5, s. 527-547.

Strauss A. L. (1977) Mirrors and Masks. The Search for Identity, London, Robertson \& Co.

Szczepanik R. (2015) Stawanie się recydywistą. Kariery instytucjonalne osób powracających do przestępczości, Łódź, Wydawnictwo Uniwersytetu Łódzkiego.

Szczepanik R. (2016) Praca jako narzędzie ekspozycji zmiany i osłabiania negatywnego wizerunku społecznego recydywistów w: Aktywność zawodowa skazanych jako obszar oddziaływań penitencjarnych, A. Jaworska (red.), Bydgoszcz, Oficyna Wydawnicza Edward Mitek, s. 25-41.

Szczepanik R., Miszewski K. (2016) Wpływ długoterminowego uwięzienia na rodziny więźniów - stan wiedzy i zaniedbane kierunki badań, „Profilaktyka Społeczna i Resocjalizacja", nr 30, s. 53-95. 
Uggen Ch. (2000) Work as a turning point in the life course of criminals: A duration model of age, employment, and recidivism, „American Sociological Review”, $\mathrm{nr} 4$, s. 529-546.

Urban B. (2004), Wzmacnianie procesu destygmatyzacji ex-dewianta jako warunek readaptacji społecznej, „Rocznik Komisji Nauk Pedagogicznych”, nr 57, s. 141-152.

Wyka A. (1993) Badacz społeczny wobec doświadczenia, Warszawa, Wydawnictwo Instytutu Filozofii i Socjologii PAN. 